\title{
An intentionality interpretation of meaning in mathematics education
}

\author{
Ole Skovsmose ${ }^{1,2}$
}

Published online: 14 October 2015

(C) Springer Science+Business Media Dordrecht 2015

\begin{abstract}
The referential theory of meaning as well as the use-oriented theory of meaning have huge impacts on the discussion of meaning in mathematics education. Here, I present a third theory in terms of an intentionality interpretation of meaning, which provides an alternative departure for the discussion of meaning in mathematics education. The importance of intentionality for understanding human phenomena was emphasised by both Brentano and Husserl. They associated intentionality with a pure stream of consciousness, which constitutes an a priori to any human experience. I agree that the notion of intentionality is important; however, I find it crucial to provide a paradigmatic uprooting of this notion and to consider it as being structured by economic, political, cultural, and discursive factors. Such real-life intentionalities constitute the basis for an intentionality interpretation of meaning. I explore this interpretation with respect to mathematics education by addressing imaginations, possibilities, obstructions, hopes, fears, stereotypes and preconceptions. I relate meaning in mathematics education to far away horizons of students' life worlds, to negotiations, to political issues, to diversity and to instrumentalism.
\end{abstract}

Keywords Intentionalities · Real-life intentionalities · Meaning in mathematics education · Intentionality interpretation of meaning $\cdot$ Politics of meaning

\section{Introduction}

Theories of meaning have been profoundly discussed in mathematics education. Several studies and perspectives are presented in Meaning in Mathematics Education (Kilpatrick, Hoyles, Skovsmose, \& Valero, 2005). Here, meaning becomes related to philosophic traditions, to implementations of new technologies, and to a variety of classroom observations. The article

Ole Skovsmose

osk@learning.aau.dk

1 Aalborg University, Skoerping, Denmark

2 State University of São Paulo, Rio Claro, Brazil 
"In the absence of meaning...." (Thompson, 2013) provides as well a profound combination of philosophical insight, theoretical overview, and specific classroom observations.

It appears, however, that the very conception of meaning is getting less attention in mathematics education. Thus, the subject indexes of the important handbooks-Atweh, Graven, Secada, and Valero (2011), Clements, Bishop, Keitel, Kilpatrick, and Leung (2013), Forgasz and Rivera (2012), and Sriraman and English (2010) - do not contain the word meaning, nor is the word meaning among in the entrances in the Encyclopedia of Mathematics Education (Lerman, 2014). Certainly, all these books include the word meaning and many aspects of meaning are addressed, but basic conceptions of meaning are not put into focus. This, however, I want to do in the following.

Theories of meaning, also with respect to mathematics education, include profound philosophic features. As a consequence, we do not have to do with regular observation-based theories. There are no classroom observations that tend to verify or falsify such theories. Theories of meaning are conceptual in nature; we have to do with suggestions for overall patterns of interpretations.

In Sect. 2, I refer to two principal philosophic interpretations of meaning, namely a referential theory of meaning and a use-oriented theory of meaning, which in turn become reflected in interpretations of meaning in mathematics education. In Sect. 3, I pay attention to the notion of intentionality, which has deep philosophic roots and plays a defining role in Brentano's interpretation of the human mind and in Husserl's conception of phenomenology. In Sect. 4, I propose to do a paradigmatic uprooting of intentionality, which becomes condensed in the notion of real-life intentionalities. With departure in this notion, I want to present an intentionality interpretation of meaning. In Sect. 5, I try to illustrate through examples what such an interpretation could imply for mathematics education. Among other things, this brings me to a conception of "politics of meaning" emphasising the profound social formatting of students' experiences of meaning. Thus, I find a "politics of meaning" to be of particular relevance when addressing issues of race, class, and gender.

In Towards a Philosophy of Critical Mathematics Education (Skovsmose, 1994), I introduced the notion of students' foregrounds and related it to intentionality. However, while intentionally is an old concept with a long and complex history, foreground is young and in need of much elaboration. In Foregrounds: Opaque Stories about Learning (Skovsmose, 2014), I did some, and I explored the overlapping between real-life intentionalities and foregrounds. In fact, one can refer to the intentionality interpretation of meaning as being a foreground interpretation of meaning. However, here, I concentrate on intentionality.

\section{Paradigmatic interpretations of meaning}

Since antiquity, the notion of meaning has constituted a philosophic issue, and Platonism represents a most elaborated suggestion for a referential theory of meaning. The meaning of a notion has to be identified as the entity to which the notion refers, and the world of proper references makes up the world of ideas. Mathematics provides a paradigmatic illustration of this, both to Plato and to all who assumed Platonism in general. The referential theory of meaning was highlighted by Augustine, and it was reformulated again and again during the whole Scholastic period. Inspired by rationalism, the referential theory turned in one direction, assuming that possible references were of a logical format. Inspired by empiricism, it turned in a different direction, assuming that possible references were of an observational nature. 
Later Gottlob Frege, also assuming a version of Platonism, elaborated a referential theory drawing on a distinction between sense and reference (see Frege, 1892; Dummett, 1981). While "sense" has to do with experiences, "reference" has to do with logic. When addressing mathematics, his idea was to concentrate on the domain of "references" and to leave aside "senses" as a physiological issue irrelevant for grasping the essence of mathematics. This referential theory of meaning provided the basis for logicism, and for the attempts to construct mathematics on a foundation of logic. ${ }^{1}$

Partly inspired by Frege, Ludwig Wittgenstein (1922) in Tractatus elaborated a referential theory of meaning in terms of a picture theory. This theory led to the formulation of the principle of verification according to which a proposition has a meaning if and only if one can point out a possible procedure for verifying the proposition. ${ }^{2}$ With departure in such an outlook, a referential theory of meaning achieved huge significance for logical positivism and related positions in the philosophy of science. ${ }^{3}$

In Philosophical Investigations, Wittgenstein (1958) abandoned any referential theory of meaning. He simply suggested that we give up looking for possible references to concepts. Instead, the meaning of a concept should be discussed in terms of its use. A notion gets its meaning, and most likely a variety of meanings, through the language games in which it may operate. Such games can be considered uses-in-contexts. By this use-oriented interpretation of meaning, Wittgenstein introduced a paradigmatic shift in the philosophy of meaning. According to Platonism and several referential theories, the social has no role to play in identifying the meaning of concepts. Other referential theories went some way to open the social dimensions. However, Wittgenstein's suggestion establishes the social as crucial for interpreting meaning. The social becomes further elaborated in speech act theory and discursive theory, which bring additional complexities to interpretations of meaning. ${ }^{4}$

Although one finds several other theories of meaning in philosophy, I restrict myself to consider the two I have just mentioned. To some extent, the discussion of meaning in mathematics education reflects these two main positions. Here, we find many ramifications of the referential theory of meaning. It has been emphasised that in order to provide meaning to mathematical concepts, it is important to point out concrete possible references for such notions. Accordingly, it was broadly assumed that manipulatives and concrete material, in general, would help bringing meaning into elementary mathematics education (see, e.g., Dienes, 1960, 1963, 1964). Some discussions about the use of computers in mathematics education also emphasised this line of argument. A different kind of operational concreteness can be experienced by students when using, say, Logo or Cabri (see, e.g., Hoyles, 2005; Laborde, 2005).

Acknowledging the referential theory, attempts have been made to establish meaning through a careful decomposition of mathematical concepts. This idea became an integral part of the New Math Movement, and I see, for instance, the textbook Modern Mathematics (Papy, 1969) as an example of how a referential theory of meaning can be formulated with a classroom

\footnotetext{
${ }^{1}$ Later, Frege's referential theory inspired the elaboration of formal semantics crucial for any computational theory. Here, we witness the huge technical applicability of a referential theory of meaning. More technical studies establishing the route for formal semantics are found in Carnap (1947), Kripke (1972) and Tarski (1936). In Montague (1974), one finds the so-called Frege semantics developed in all technical details.

2 See, for instance, Carnap (1932) and Hempel (1959).

${ }^{3}$ See, for instance, Ayer (1959) and Reichenbach (1966). For contributions within analytic philosophy to the discussion for meaning, see, for example, Grice (1989), Quine (1960) and Schiffer (1972).

${ }^{4}$ See, for instance, Austin (1962, 1970); Searle (1983) and Torfing (1999).
} 
practice in mind. Thus, the meaning of, say, the notion of function has to be established through a careful elaborated route that introduces the notions: set, ordered couple, set of ordered couples, before reaching the very notion of function (see Biehler, 2005, for a recent interpretation of meaning related to decompositions of concepts). ${ }^{5}$

Wittgenstein's use-oriented interpretation of meaning has also had a huge impact in mathematics education. Thus, several ethnomathematical studies apply a use-oriented interpretation of meaning; Knijnik (2012), for example, makes explicit reference to Wittgenstein. A particular instance of an ethnomathematical concept becomes interpreted as making part of a language game, which in turn can demonstrate family resemblances to other language games. Different forms of mathematics become interpreted as different forms of language games, and as a consequence, meanings of mathematical notions become associated to uses-in-contexts.

However, mathematics education does not simply operate within a straightforward referential and use-oriented duality. Here, one finds suggestions for interpreting meaning that combines a variety of ideas and assumptions. ${ }^{6}$ As illustration, let me just refer to a few examples. Ormell (1991) addresses the relationship between what he refers to as the ordinary meaning of a notion and its more specific mathematical meaning. In this way, he explores the conception of meaning in terms of familiarity. One can think of this as a suggestion for the relevance of presenting a multiplicity of referential environments for mathematical notions, but also as an example of Wittgenstein's use-oriented interpretation of meaning. Voigt (1996) emphasises the importance of negotiating meaning, and in this way, the social becomes principal for the construction of meaning. Negotiations of meaning may concern possible uses, but can in fact reach much broader. Radford (2009) points out that gestures matter for the conception of mathematical meanings. This suggestion brings the discussion of meaning into a new terrain, where the duality between subject and objects to some extent becomes deactivated.

In this article, I suggest an intentionality-interpretation of meaning as being relevant for mathematics education. This theory diverges from both a referential theory of meaning and a use-oriented theory of meaning. However, let me emphasise that my interpretation shares with Wittgenstein's use-interpretation the emphasis on the social aspects of meaning. A fact I want to emphasise through the conception of "politics of meaning".

\section{Pure intentionality}

The notion of intentionality plays a crucial role in Franz Brentano's interpretation of psychology and in Edmund Husserl's phenomenology. Through their works this notion achieves a unique position in philosophy.

Through his study Psychology from an Empirical Standpoint (Pschycologie vom empirischen Standpunkt) from 1874, Brentano wants to provide psychology with a new beginning as an exact science. He does not want to maintain psychology as a further amplification of philosophic speculations about mind and soul, as had been intensively

\footnotetext{
${ }^{5}$ With departure in Pierce's ideas, a profound ramification of a referential theory of meaning has become expressed in terms of the semiotic triangle. These ideas have also inspired much research in mathematics education (see, for instance, Otte, 2006; Steinbring, 1997).

${ }^{6}$ For a presentation of more general interpretations of meaning in mathematics education, see, for example, Howson (2005) and Otte (2005). For more particular studies see, for example, Bussi (2005), Dreyfus and Hillel (1998), Hillel and Dreyfus (2005), and Kaiser (2008).
} 
cultivated during the Romantic period. As highlighted by the title, Brentano sees psychology as an empirical science; however, he does not want to elaborate it according to the pattern set by natural sciences. He wants to base psychology on specific observations of its own domain: the human mind.

Brentano is deeply inspired by Aristotle, clearly demonstrated in his study The Psychology of Aristotle: In Particular his Doctrine of the Active Intellect (Die Psychologie des Aristoteles: Insbesondere seine Lehre vom Nous Poietikos) from 1872 (Brentano, 1997). With this departure, Brentano elaborates his own duality position: the mind is active, while matter is not; the mind can direct itself, matter not; the mind can demonstrate intentionalities, matter not. Thus the notion of intentionality becomes crucial for expressing how psychology is different from the natural sciences. Wilhelm Dilthey insisted on the existence of a paradigmatic difference between the humanities (Geisteswissenschaften) and the natural sciences. ${ }^{7}$ Following Brentano's suggestion, this difference can be expressed in terms of intentionality.

The following quotation from Psychology from an Empirical Standpoint makes part of what is referred to as Brentano's intentionality passage:

Every mental phenomenon is characterised by what the Scholastics of the Middle Ages called intentional $[\ldots]$ inexistence of an object, and what we might call [...] reference to a content, direction toward an object [...], or immanent objectivity. Every mental phenomenon includes something as object within itself... (Brentano, 1995, p. 88)

Brentano claims that there is something particular to a mental phenomenon: it is directed towards something which he refers to as intentional in-existence. This directedness establishes the universal characteristic of the mind has taken place. According to Brentano, directedness is an a priori phenomenon, which provides the universal condition for human experience. It operates before any social structuring of the mind. In this sense, every mental phenomenon is intentional. This brings Brentano to formulate the duality thesis in the following way:

This intentional in-existence is characteristic exclusively of mental phenomena. No physical phenomenon exhibits anything like it. We can, therefore, define mental phenomena by saying that they are those phenomena which contain an object intentionally within themselves. (p. 89)

Thus, the very notion of intentionality, including the conception of in-existence, provides the paradigmatic distinction between mind and matter. ${ }^{8}$

Brentano (1995) goes on to claim that this duality has a strong epistemological implication: "Inner perception is not merely the only kind of perception which is immediately evident; it is really the only perception in the strict sense of the word" (p. 91). The German word translated into "perception" is Wahrnehmung, which literally means "grasping the truth". So, Brentano claims that through inner perception, one can grasp truths, and that inner perception provides us with the only possibility for doing so: "Mental phenomena, therefore, may be described as the only phenomena of which perception [Wahrnehmung] in the strict sense of the word is possible" (p. 91).

Edmund Husserl is deeply inspired by Brentano. He generalises Brentano's ideas about "inner perception" and "grasping the truth" into a general phenomenological outlook.

\footnotetext{
${ }^{7}$ See, for instance, Reid (2001).

${ }^{8}$ In the intentionality passage, in-existence is written as inexistence, without a hyphen. This difference, however, has no implications for the interpretation of the notion.
} 
Through inner perception and only through such perception, one can grasp truths. As a consequence, phenomenology, taking departure in exactly this form of perception, provides the ultimate foundation of any kind of knowledge. In this generalisation of Brentano's ideas into phenomenology, Husserl maintains the notion of intentionality as defining for human perceptions and experiences. Intentionality represents the pure stream of consciousness, within which all human experiences are located.

\section{Real-life intentionalities}

I agree with Brentano and Husserl that the notion of intentionality is crucial for interpreting human phenomena. Like them, I discard any attempt of reductionism trying to define intentionalities through observational entities. ${ }^{9}$ However, I diverge radically from them when it comes to the very interpretation of intentionality.

While they associate intentionality with a pure directedness of the mind that operates before any social structuring, I acknowledge the profound social configuration of intentionalities. In order to emphasise this, I talk about real-life intentionalities. In Part IV of my book Foregrounds (Skovsmose, 2014), I present more carefully the notion of real-life intentionalities; here, I restrict myself to illustrate their configuration through an example.

Let us consider the apparent simple action of me buying a pair of shoes. I intend to buy tennis shoes. Which pair do I choose? Some pairs I like; some I could not even dream of buying. My intentionalities directing the apparent straightforward act of buying a pair of shoes are structured through many factors. Even though I do not think that I pay particular attention to announcements and fashion, I am subjected to a range of inputs that form my intentionalities. Anyway, in the end, I decided on buying a particular pair of shoes. That became my decision. But, in what sense was it really my decision. Precisely due to the profound social structuring of intentionalities, actions may reflect preconceptions, superstitions, fashions and so forth. Still, is this fabric of intentionalities that direct my act of buying a pair of shoes. ${ }^{10}$

I see learning as action, and as a consequence, I find intentionalities to be crucial for analysing learning activities and for interpreting students' experiences of meaning or meaninglessness related to such activities. ${ }^{11}$ For instance, when students want to engage in mathematics and to do homework, we have to do with a most complex phenomenon. Doing homework is an example of learning as action, but the intentionality included in this action is complex and opaque. The students could decide to do the homework because they are interested in the topic. They could also fear the teacher. They could acknowledge the aspirations of their parents. They could want to get better marks. Or they might realise that there is no point of doing homework, as they do not see any possibility for them to come to engage in further studies. The intentionalities that direct their learning represent a complex social fabric.

\footnotetext{
${ }^{9}$ Behaviourism is an example of such reductionism (see, e.g., Skinner, 1957; Watson, 1913, 1914, 1919).

${ }^{10}$ Interpretations of action open a huge philosophic terrain. See, for example, Brand (1984), Mele (2010) and Searle (1983) for a discussion of actions and intentionality. See O’Connor and Sandis (2010) for a general overview of the field.

${ }^{11}$ One could naturally consider if all kind of learning can be interpreted as actions: What about soldiers learning something under command? What about the small child learning their mother tongue? Are we dealing here with examples of learning as action? Although, I am not going to insist that all kinds of learning are intentional, I find that it is important to consider students' intentionalities when discussing learning.
} 
I consider intentionalities an opaque phenomenon, also to the persons themselves. They are formed through a range of historic, economic, political, cultural and discursive factors, while simultaneously they operate as the person's intentionalities. Thus, when the students decide to do or not to do homework, it is their decision, which in turn is socially conditioned. This apparent contradiction, I refer to as the paradox of intentionality. My point is that we cannot eliminate this paradox. It accompanies real-life intentionalities and makes part of any intentionality interpretation of meaning. ${ }^{12}$

Let me summarise the intentionality interpretation of meaning in the following way: (1) When talking about intentionalities, we always have real-life intentionalities in mind. They provide directedness of the human mind, and they make integral part of human actions. (2) The paradox of intentionality has to be acknowledged, implying that even though intentionalities are defining for particular actions, they are social fabrics. (3) Meaning is conceptualised through the directedness of intentionalities, and as a consequence, meaning becomes discussed in terms of opportunities, imaginations, visions, hopes, aspirations, as well as in terms of obstructions, fears and frustrations.

\section{Intentionalities and meanings in mathematics education}

In this section, I am going to present some examples in order to illuminate what an intentionality interpretation of meaning could mean for mathematics education. Thus, I want to illustrate how intentionalities form experiences of meaning. ${ }^{13}$

\subsection{Example 1: meaning along far remote horizons}

In a school in Rio Claro, Brazil, the mathematics teacher was planning to do some project work. She proposed different topics, and so did the students. They suggested working on surfing. The teacher, however, had some doubts about this proposal. The school was situated in a poorer neighbourhood in Rio Claro, a city in the interior of the São Paulo State. She knew it was most unlikely that the students had been travelling, and only a few, if any, might have ever seen the ocean. How could a project about surfing make any sense to them? ${ }^{14}$

If we think of meaning as established through references to situations familiar to the students, the teacher's worry seems justified. It would be difficult for the students to connect features from their environment with surfing; the project seems devoid of meaning. The

\footnotetext{
${ }^{12}$ The paradox of intentionality raises a profound methodological challenge. There is no simple way of identifying intentionalities, being both personal and socially structured. Thus, no straightforward observational approach would function, nor any regular phenomenological approach. This methodological complexity is addressed in Skovsmose (2014). Here, a reference is made to the conception of inter-viewing, a notion coined by Kvale (1996), which brings about some suggestions for researching students' foregrounds as well as their intentionalities.

${ }^{13}$ Let me emphasise that I concentrate on the students' experiences of meaning. Naturally, one could apply many other perspectives as well. Parents could see meaning as being related to their children's opportunities for further education. Teachers could interpret meaning as having to do with the quality of the lessons. Textbook authors could see meaning as depending on the sequential organisation of the textbook. Politicians might think of meaning in terms of the overall quality of the educational programmes as expressed through international comparisons. Companies might think of meaning as representing possible competencies of the coming workforce.

${ }^{14}$ For a presentation of this example, see also Skovsmose and Penteado (2015).
} 
conclusion appears the same if we think of meaning in terms of use. Far away from the sea, surfing is a useless activity.

However, if we consider learning as action and meaning as having to do with intentionalities, the interpretation becomes different. We have, for instance, to consider the students' hopes and aspirations. We have to consider their imaginations, which could constitute possible directions for their learning activities, and surfing could make up fascinating images. Meaning is constructed through the direction of intentionalities, and these directions are formed through a range of factors. Why did the children from Rio Claro want to work with surfing? Maybe they had dreams of getting to the ocean. Maybe they had watched a programme about surfing on the TV. Maybe they imagined becoming famous, and Brazil has many famous surfers. Maybe they wanted to address something out of reach, at least for the moment. Their imaginations could be structured in all possible ways, also by any forms of stereotypes. Anyway, it is such imaginations that bring real-life intentionalities into the students' learning activities and provide them with meaning. In fact, the surfing project was concluded with success and with much dedication from the students.

Meaningful mathematics education might be located along the horizons of the students' life-worlds, even when such horizons appear to be far away. Intentions might reach far beyond the children's lived-through realities, what they are familiar with, what they direct can refer to, and what they can experience as being useful. In this sense, an intentionality interpretation of meaning points out other features of meaning than a referential or a use-oriented theory of meaning would do.

\subsection{Example 2: meaning through negotiation}

Certainly, an experience of meaning may have to do with familiarity. This idea has, for instance, been emphasised by contributions to mathematics education for social justice. It has been claimed that a mathematics education could take departure in the students' daily life experiences of social problems and develop a critical consciousness. One can read about projects having to do with elections, immigration, spread of HIV-AIDS, criminalisation of youth of colour, sexism and minimum wages (see, for instance, Bartell, 2012; Gutstein, 2006, 2012; Peterson, 2012). I see the success of such projects as having to do with students' experiences of meaning. However, not due to the fact that political issues and topics about social justice automatically become experienced as meaningful by the students. Meanings become experienced when students establish their intentionalities in the learning process, and as mentioned with reference to Voigt (1996), this can be a complex process of negotiation. Intentionalities are socially structured, and there are many factors influencing what the students give priority to, and what they tend to ignore.

As an illustration, I can refer to a situation in Brazil (see Biotto Filho, 2015) where a mathematics teacher tried to engage students who were living in a poor and violent neighbourhood with problems having to do to with violence, crimes, drug dealing, etc. This approach was not well received. And, maybe it is not difficult to see why, if we bring the familiarity interpretation of meaning to an extreme: by engaging children from a poor neighbourhood in investigating prices of used clothes, and children from wealthy neighbourhoods in calculating the size of swimming pools. The intentionality interpretation of meaning brings a warning to any simplistic interpretation of meaning in terms of familiarity. The experience of meaning also has to do with imaginations, hopes and fears. 
Intentions can be directed and redirected. So, when projects about elections, immigration, minimum wages, etc. were experienced as meaningful by the students, it has much to do with the complex interactive processes that established the students' intentionalities as integral part of their learning process. These interactive processes among students and between teachers and students are educational as well as a political. Through these processes, intentionalities become constructed, directed and redirected. I find such negotiations to provide a crucial feature of mathematics education for social justice.

Thus, one cannot expect that addressing specific examples of social injustice brings some genuine meaning to mathematics education. An intentionality interpretation of meaning abandons any conception of the existences of "genuine" meaning. Instead, it brings us to acknowledge the importance of negotiating meaning.

\subsection{Example 3: politics of meaning}

Intentionalities can be formed by possibilities as well as by obstructions. As illustration, let us consider the general situation of women during the 1950s and 1960s in Denmark. I grew up during that time and witnessed a period of technological optimism, which also included a profound exclusion of women. When in 1968, I came to study mathematics at Copenhagen University, I remember only one woman among the academic staff.

In order to understand the limited participation of women in mathematics-dense studies and to interpret their achievements in mathematics, I find it important to consider the social formatting of their possible intentionalities for engaging with mathematics. How did society at the time configure women's perspectives for pursuing career possibilities through the learning of mathematics? What space for possible directions of intentionalities did society provide? How did society format hopes and aspirations of young women? We have to do with a political formatting of possible experiences of meaning — a formatting including layers of sexism. ${ }^{15}$

Intentionalities can be socially formed also by stereotypes of any form. Sexism can prevent girls and racism can prevent black students from experiencing meaning in engaging with mathematics. Thus, devastating preconceptions exercised during the Apartheid regime in South Africa claimed that further technical studies were not for black students. In fact, it was simply forbidden for black students to study engineering and similar topics. This constitutes a most direct and violent obstruction for directing intentionalities into the learning of mathematics. The students' experience of meaning, or lack of meaning, is far from being a personal issue; it is a social issue; it is a political issue.

Libertarianism is a philosophic position which claims that human beings in fact can make decisions, which are expressions of a free will. Thus, libertarianism was celebrated by existentialism, and Sartre (1989) emphasised that human beings were free to make their choices and, as a consequence, that they were responsible for what they were doing. The existentialist libertarianism appears a consequential extension of the conception of intentionality as a pure stream of consciousness. I do not assume, however, any form of libertarianism. I find that actions are performed by the person, but simultaneously that intentionalities operating through the action are formed through a range of social factors. This feature of the paradox of intentionality is crucial when considering a politics of meaning with respect to mathematics education.

\footnotetext{
${ }^{15}$ I have referred to a particular period in Denmark. Certainly, I am not suggesting that this is the only period of sexism, or that sexism disappeared after that. I have referred to this period as just one example.
} 


\subsection{Example 4: diversity of meanings}

In Skovsmose, Alrø, Valero, Silvério, and Scandiuzzi (2008), we present interviews with some Indian students living in Brazil. We asked them about their aspirations for the future and how they saw mathematics related to these aspirations. One student wanted to remain in the Indian community. He liked to work in the fields, and he explained about the relevance of mathematics in relation to this work, for instance for calculating the size of the field when planning the sowing. He also mentioned that mathematics was relevant for providing a fair distribution of the crops. In fact, he found much meaning in mathematics by referring to its usefulness in everyday situations.

Another student wanted to study medicine. He wanted to graduate from a university, and then to return to the Indian community. He pointed out that main problems in Indian communities have to do with health, and that he would like to be able to address such problems. He was fully aware that mathematics was crucial for entering university studies in medicine. He was ready to study trigonometry, algebra, matrix calculus, and so forth, although he did not know the exact nature of the relevance of such topics for medicine. He experienced a meaning of studying such issues; however, the meaningfulness had nothing to do with familiarity; instead, it had to do with his priorities. The student had visions for the future, and the meaning he experienced related to these visions.

Both Indian students were directing their intentionalities, although in different directions. This directing provided meaning to their learning of mathematics. So, even though we have to do with students from the same community experiencing the same life conditions, the horizons of their life-worlds can be very different. This difference provides different experiences of meaning. Thus, the social formatting of meaning is not uniform. Nor is it a total formatting, as meaning continues to integrate personal visions and priorities.

\subsection{Example 5: meaning and instrumentalism}

In the USA, the Algebra Project was organised by Bob Moses (see Moses \& Cobb, 2001). The aim of the project was to improve the quality of mathematics education in poor communities and to provide better access to further education for black students. Mathematics exercises a powerful gatekeeping function, and Moses saw access to algebra as playing a particular role for students passing through the gate. He wanted to ensure that black students were not obstructed in their career opportunities by low scores in mathematics.

Thus, the aim of the Algebra Project was not, as in many other examples of mathematics education for social justice, to provide critical readings of the socio-political contexts and to use mathematics in order to reveal forms of suppression. The main aim was to ensure black students' access to the established educational system. Thus, the idea was not to construct a new curriculum, but rather to engage the students in the existing curriculum. This curriculum provided the logic of the gatekeeping, and the aim was to help students mastering this logic.

Students participating in the Algebra Project might experience meaning in what they were doing, but this experience can hardly be interpreted in terms of familiarity. In this case, meaningfulness might be experienced in terms of possibilities that a mastering of the pregiven curriculum might provide for the students. The meaning has to do with the students' hopes, priorities and imaginations; it has as well to do with overcoming fears and aversions.

This observation brings us to Stieg Mellin-Olsen's (1981) notion of instrumentalism, a rationale for learning mathematics not related to the content of the learning, but to the benefits 
that could be achieved through the learning. An expression of such instrumentalism can be found in Hardy's (1967) famous book A Mathematician's Apology where he states,

I do not remember having felt, as a boy, any passion for mathematics, and such notions as I have had of a career of a mathematician were far from noble. I thought of mathematics in terms of examinations and scholarships: I wanted to beat the other boys, and this seemed to be the way in which I could do so most decisively. (p. 144; emphasis in original)

To the young Hardy, mathematics became an instrument for "beating the others" and certainly different forms of instrumentalism can be related to the learning of mathematics: one may pass a test; one may get access to further education; and one may get a good job. In many cases, it seems possible to interpret students' intentionalities in learning as well as their experiences of meaning as an expression of instrumentalism. When young, Hardy did not experience any passion for mathematics; his intentions in learning were instrumental. Similarly, one could interpret the whole Algebra Project as an expression of an instrumentalism - a noble instrumentalism maybe. However, whatever forms of learning intentions we have to do with, we can think of them as providing meaning to the learning of mathematics.

The experience of meaningfulness is formed through the students' intentionalities. However, intentionalities can be of very different nature. They need not be rooted in any "noble" aspirations, but could be an expression of also a dubious instrumentalism. Intentions are socially and politically formed. In fact one cannot assume the existence of intentionalities that could be called the person's genuine intentionalities. Any intentionality operates through a formatting, and one might consider the relevance of introducing the notion of "imposed intentionalities" as a way of acknowledging the paradox of intentionality. Still, the direction of intentionalities provides experiences of meaning.

\section{Summary}

The discussion of meaning in mathematics education has drawn on ramifications of the referential theory of meaning. It has as well drawn profoundly on the use-oriented interpretation of meaning, as suggested by Wittgenstein. By interpreting learning as action and meanings of actions in terms of intentionalities, I try to bring the discussion of meaning in mathematics education into a new landscape. I want to highlight an intentionality interpretation of meaning as crucial for mathematics education.

But, we have to be careful, as the notion of intentionality has been operating in a paradigm very remote from the one in which I want to engage. Thus, intentionality is defining for Brentano and Husserl's conceptions of the human mind: they see intentionality as an expression of the pure mind, and as representing the essence of the human experience. Lev Vygotsky, for instance, was aware of Brentano's contributions to psychology, and Vygotsky makes reference to Brentano, but occasionally. I am convinced that Vygotsky saw Brentano as representing idealism in psychology and as ignoring the social formation of the mind, and Vygotsky was completely right: there is not much space left for the social in Brentano's view on psychological phenomena.

However, I do not want to abandon intentionality as an irrelevant notion. Instead, I suggest a paradigmatic uprooting of this notion and to consider intentionalities in the format of real-life intentionalities. Such intentionalities are crucial human phenomena; they are social 
phenomena, and they are political. Thus, intentionalities can express priorities and stereotypes also of the most dubious nature. Still, it is such intentionalities we have to address when we want to interpret students' experiences of meaning in mathematics education.

Acknowledgments I want to thank Denival Biotto Filho, Peter Gates, Renato Marcone, Raquel Milani, Miriam Penteado, and Guilherme Gomes da Silva for their many helpful comments and suggestions.

\section{References}

Atweh, B., Graven, M., Secada, W., \& Valero, P. (Eds.). (2011). Mapping equity and quality in mathematics education. New York: Springer.

Austin, J. L. (1962). How to do things with words. Oxford: Oxford University Press.

Austin, J. L. (1970). Philosophical papers (2nd ed.). (J. O. Urmson \& G. J. Warnock, Eds.). Oxford: Oxford University Press.

Ayer, A. (Ed.). (1959). Logical positivism. New York: The Free Press.

Bartell, T. G. (2012). Is this teaching mathematics for social justice? Teachers' conceptions of mathematics classrooms for social justice. In A. A. Wager \& D. W. Stinson (Eds.), Teaching mathematics for social justice: Conversations with mathematics educators (pp. 113-125). USA: NCTM, National Council of Mathematics Teachers.

Biehler, R. (2005). Reconstruction of meaning as a didactical task: The concept of function as an example. In J. Kilpatrick, C. Hoyles, \& O. Skovsmose (Eds.), Meaning in mathematics education (pp. 61-81). New York: Springer.

Biotto Filho, D. (2015). Quem não sonhou em ser um jogador de futebol? Trabalho com projetos para reelaborar foregrounds (Unpublished doctoral dissertation). Universidade Estadual Paulista Júlio de Mesquita Filho, Teses, Rio Claro.

Brand, M. (1984). Intending and acting. Cambridge: MIT Press.

Brentano, F. (1977). The psychology of Aristotle: In particular his doctrine of the active intellect (R. George, Trans.). Berkeley: University of California Press.

Brentano, F. (1995). Psychology from an empirical standpoint (A. C. Rancurello, D. B. Terrell, \& L. L. McAlister, Eds.). London: Routledge.

Bussi, M. G. B. (2005). The meaning of conics: Historical and didactical dimensions. In J. Kilpatrick, C. Hoyles, \& O. Skovsmose (Eds.), Meaning in mathematics education (pp. 39-60). New York: Springer.

Carnap, R. (1932). The elimination of metaphysics through logical analysis of language. In A. Ayer (Ed.), Logical positivism (pp. 60-81). New York: The Free Press.

Carnap, R. (1947). Meaning and necessity: A study in semantics and modal logic. Chicago: University of Chicago Press.

Clements, M. A. K., Bishop, A., Keitel, C., Kilpatrick, J., \& Leung, F. K. S. (Eds.). (2013). Third international handbook of mathematics education. New York: Springer.

Dienes, Z. P. (1960). Building up mathematics. London: Hutchinson.

Dienes, Z. P. (1963). An experimental study of mathematics-learning. London: Hutchinson.

Dienes, Z. P. (1964). The power of mathematics. London: Hutchinson.

Dreyfus, T., \& Hillel, J. (1998). Reconstruction of meanings for function approximation. International Journal of Computers for Mathematical Learning, 3(2), 93-112.

Dummett, M. (1981). The interpretation of Frege's philosophy. Cambridge: Harvard University Press.

Forgasz, H., \& Rivera, F. (Eds.). (2012). Towards equity in mathematics education: Gender, culture, and diversity. New York: Springer.

Frege, G. (1892). On sense and reference. In P. Geach \& M. Black (Eds.), Translations from the philosophical writings of Gottlob Frege (pp. 56-78). Oxford: Basil Blackwell.

Grice, P. (1989). Meaning. Studies in the way of words (pp. 213-223). Cambridge, MA: Harvard University Press.

Gutstein, E. (2006). Reading and writing the world with mathematics: Toward a pedagogy for social justice. New York and London: Routledge.

Gutstein, E. (2012). Reflections on teaching and learning mathematics for social justice in urban schools. In A. A. Wager \& D. W. Stinson (Eds.), Teaching mathematics for social justice: Conversations with mathematics educators (pp. 63-78). USA: NCTM, National Council of Mathematics Teachers.

Hardy, G. H. (1967). A mathematician's apology. Cambridge: Cambridge University Press.

Hempel, C. G. (1959). The empiricist criterion of meaning. In A. Ayer (Ed.), Logical positivism (pp. 108-129). New York: The Free Press. 
Hillel, J., \& Dreyfus, T. (2005). What's a best fit? Construction of meaning in a linear algebra session. In J. Kilpatrick, C. Hoyles, \& O. Skovsmose (Eds.), Meaning in mathematics education (pp. 181-203). New York: Springer.

Howson, G. (2005). "Meaning” and school mathematics. In J. Kilpatrick, C. Hoyles, \& O. Skovsmose (Eds.), Meaning in mathematics education (pp. 17-38). New York: Springer.

Hoyles, C. (2005). Making mathematics and sharing mathematics: Two paths to co-constructing meaning. In J. Kilpatrick, C. Hoyles, \& O. Skovsmose (Eds.), Meaning in mathematics education (pp. 139-158). New York: Springer.

Kaiser, G. (2008). Meaning is mathematics education: Reflections from various perspectives. Retrieved from https://www.unige.ch/math/EnsMath/Rome2008/WG5/Papers/KAIS.pdf

Kilpatrick, J., Hoyles, C., Skovsmose, O., \& Valero, P. (Eds.). (2005). Meaning in mathematics education. New York: Springer.

Knijnik, G. (2012). Differentially positioned language games: Ethnomathematics from a philosophical perspective. Educational Studies in Mathematics, 80, 87-100.

Kripke, S. (1972). Naming and necessity. Cambridge: Harvard University Press.

Kvale, S. (1996). InterViews: An introduction to qualitative research interviewing. Thousands Oaks: Sage Publications.

Laborde, C. (2005). The hidden role of diagrams in students' construction of meaning in geometry. In J. Kilpatrick, C. Hoyles, \& O. Skovsmose (Eds.), Meaning in mathematics education (pp. 159-179). New York: Springer.

Lerman, S. (Ed.). (2014). Encyclopedia of mathematics education. New York: Springer.

Mele, A. R. (2010). Intention. In T. O'Connor \& C. Sandis (Eds.), A companion to the philosophy of action (pp. 108-113). Chichester: Wiley-Blackwell.

Mellin-Olsen, S. (1981). Instrumentalism as an educational concept. Educational Studies in Mathematics, 12, 351-367.

Montague, R. (1974). Formal philosophy: The selected papers of Richard Montague (R. Thomason, Ed.). New Haven: Yale University Press.

Moses, R. B., \& Cobb, C. E. (2001). Radical equations: Civil rights from Mississippi to the algebra project. Boston: Beacon.

O'Connor, T., \& Sandis, C. (Eds.). (2010). A companion to the philosophy of action. Chichester: WileyBlackwell.

Ormell, C. P. (1991). How ordinary meaning underpins the meaning of mathematics. For the Learning of Mathematics, 11, 25-30.

Otte, M. (2005). Meaning and mathematics. In J. Kilpatrick, C. Hoyles, \& O. Skovsmose (Eds.), Meaning in mathematics education (pp. 231-260). New York: Springer.

Otte, M. (2006). Mathematical epistemology from a Peircean semiotic point of view. Educational Studies in Mathematics, 61, 11-38.

Papy, G. (1969). Modern mathematics (Vol. 1). London: Macmillan Publication Company.

Peterson, B. (2012). Numbers count: Mathematics across the curriculum. In A. A. Wager \& D. W. Stinson (Eds.), Teaching mathematics for social justice: Conversations with mathematics educators (pp. 147-159). USA: NCTM, National Council of Mathematics Teachers.

Quine, W. V. O. (1960). Word and object. Cambridge: MIT Press.

Radford, L. (2009). Why do gestures matter? Sensuous cognition and the palpability of mathematical meanings. Educational Studies in Mathematics, 70(2), 111-126.

Reichenbach, H. (1966). The rise of scientific philosophy. Berkeley: University of California Press.

Reid, J. (2001). Dilthey's epistemology of the Geisteswissenschaften: Between Lebensphilosophie and Wissenschaftsteorie. Journal of the History of Philosophy, 39(3), 407-436.

Sartre, J.-P. (1989). Being and nothingness (H. E. Barnes, Trans.). London: Routledge.

Schiffer, S. (1972). Meaning. Oxford: Oxford University Press.

Searle, J. (1983). Intentionality: An essay in the philosophy of mind. Cambridge: Cambridge University Press.

Skinner, B. F. (1957). Verbal behaviour. New York: Appleton-Century-Crofts.

Skovsmose, O. (1994). Towards a philosophy of critical mathematics education. Dordrecht: Kluwer Academic Publishers.

Skovsmose, O. (2014). Foregrounds: Opaque stories about learning. Rotterdam: Sense Publishers.

Skovsmose, O., \& Penteado, M. G. (2015). Mathematics education and democracy: An open landscape of tensions, uncertainties, and challenges. In L. D. English \& D. Kirshner (Eds.), Handbook of international research in mathematics education (3rd ed., pp. 359-373). New York: Routledge.

Skovsmose, O., Alrø, H., Valero, P., Silvério, A. P., \& Scandiuzzi, P. P. (2008). "Before you divide you have to add”: Inter-viewing Indian students' foregrounds. In B. Sriraman (Ed.), International perspectives on social justice in mathematics education. The Montana mathematics enthusiast monograph 1 (pp. 209-230). Charlotte: Information Age Publishing, Inc. 
Sriraman, B., \& English, L. (Eds.). (2010). Theories of mathematics education: Seeking new frontiers. New York: Springer.

Steinbring, H. (1997). Epistemological investigation of classroom interaction in elementary mathematics teaching. Educational Studies in Mathematics, 32, 49-92.

Tarski, A. (1936). The semantic conception of truth and the foundations of semantics. Philosophy and Phenomenological Research, 4(3), 341-376.

Thompson, P. W. (2013). In the absence of meaning. In K. Leatham (Ed.), Vital directions for research in mathematics education (pp. 57-93). New York: Springer.

Torfing, J. (1999). New theories of discourse: Laclau, Mouffe and Žižek. Oxford: Wiley-Blackwell.

Voigt, J. (1996). Negations of mathematical meaning in classroom processes: Social interaction and learning mathematics. In L. P. Steffe, P. Nesher, P. Cobb, G. A. Golding, \& B. Greer (Eds.), Theories of mathematical learning (pp. 21-50). Mahwah: Lawrence Erlbaum.

Watson, J. B. (1913). Psychology as the behaviourists view it. Psychological Bulletin, 31(10), 755-776.

Watson, J. B. (1914). Behaviour: An introduction to comparative psychology. New York: Holt.

Watson, J. B. (1919). Psychology for the stand-point of a behaviourist. Philadelphia: Lippincott.

Wittgenstein, L. (1922). Tractatus logico-philosophicus (C. K. Ogden, Trans.). London: Routledge.

Wittgenstein, L. (1958). Philosophical investigations (2nd. ed.). (G. E. M. Anscombe, Trans.). Oxford: Basil Blackwell. 